\title{
IMPACTS OF KHAPRA BEETLE (T. GRANARIUM EVERTS) ONTO MARKETING PRICE AND RELEVANT TRAITS IN BREAD WHEAT (T. AESTIVUM L.)
}

\author{
ÖZBERK, F. \\ Akcakale Vocational College, The University of Harran, Sanlurfa, Turkey \\ (e-mail: fethiye@harran.edu.tr; phone:+90-505-527-5003) \\ (Received $4^{\text {th }}$ Jul 2018; accepted $3^{\text {rd }}$ Sep 2018)
}

\begin{abstract}
This research aimed to inspect the influence of khapra beetle (T. granarium Everts, 1898) onto marketing price and relevant traits in the controlled conditions in the laboratory of department of field crops of Faculty of Agriculture in the University of Harran in the south-east Anatolia. Laboratory experiment including larvae production was carried out employing 10 bread wheat advanced lines derived from CIMMYT (International Wheat and Corn Improvement Center) from 22 November 2017 and 29 April 2018. A split plot experimental design where the larval infestation levels are main plots and entries as sup plots with 3 replications was employed. Various physical, grain quality characteristics and marketing prices were scored initially and at nearly 40,80 and 120 days after starting date. The results revealed that quality parameters declined significantly at the end of study. Geometric mean of weight loss was $8 \mathrm{~kg}$ ton $^{-1}$. This was $32.7 \mathrm{~kg}^{-1}$ ton $^{-1}$ at the end of study. Comparing ceiling prices at the local commodity market, marketing price loss of khapra damaging grains excluding parity loss of Turkish Lira against US dollar for 120 days was 30.8 USD ton $^{-1}$. It was concluded that there were response differences to khapra beetle among the entries regarding quality characteristics and marketing prices. Entry number of 9, 6 and 10 were the least weight loosing genotypes and 9, 1 , and 10 were the least affected genotypes from marketing price declines due to khapra damaging.
\end{abstract}

Keywords: khapra damage, common wheat, weight and quality losses, economical loss

\section{Introduction and literature review}

Khapra beetle, Trogoderma granarium Everts (Coleoptera: Dermestidae) is one the worst pest of cereals and many other stored products (Ahmedani et al., 2011, 2009, 2007). Its undeniable economic importance relies on its ability to cause huge physical and quality losses in the stored grains by feeding and increasing temperature of storage environment making them liable to be invaded by some other pests including fungi and bacteria (Sayed et al., 2006; Ahmedani et al., 2009, 2007). It has tough larval ability to withstand starvation as long as three years under very low relative humidity (Ahmedani et al., 2009). Larvae feed from embryo initially and later consume the whole grain. This results in a hollow in the grain and only the seed coat remains (Ahmedani et al., 2009). The youngest larvae cannot feed on whole grain and is able to survive utilizing from deteriorated grains. Elderly larvae cannot eat whole grains. Rate of population increase may reach to 12.5 times in a month at $37^{\circ} \mathrm{C}$ (Anonymous, 2005). Adults have no long life span and do not result in significant damage in grains (Ahmedani et al., 2007).

Parameters of grain quality reduce due to ending up of nutrients such as, total carbohydrates, crude fat, sugars, real protein content and sedimentation. Contrary, damaging khapra beetle increases grain moisture, total protein and crude fiber (Jood et al., 1993, 1996; Jood and Kapoor, 1993). Moreover anti nutrient polyphenol and phytic acid increase significantly (Kumar and Srivastava, 2017). Khapra beetle occurs in large scale in Northern hemisphere including Europe, Middle East, Central and Southern Asia (Ahmedani et al., 2007). 
Post-harvest losses due to the storage pests were guessed to be up to $9 \%$ in developed countries whereas it could reached up to $20 \%$ in developing countries (Yadav et al., 2018). Post-harvest losses for grains in India were 7-10\% of total production from field to purchasers and 4-5\% at marketing (Yadav et al., 2018). In Pakistan, estimated storage loss for food grains due to pests was 4-10\% (Hugue et al., 1969), 5.08\% (Chaudhry, 1980), 5\% (Ahmad, 1984), and 3.5-25.5\% (Irshad and Baloch, 1985). Varietal differences were also detected in response to khapra beetle damage (Ahmedani et al., 2011, 2009). Average weight loss at $36^{\circ} \mathrm{C}$ and $15 \%$ infestation level may reach to $2.6 \%$ with a $24 \%$ viability loss (Prasad et al., 1977). Weight loss may rise to $16.36 \%$ in wheat (Girish et al., 1975). Turkey is an important grain producer among top-ten countries in the world (FAO Stat, 2009) and host for many storage pests (Ekmekçi and Ferizli, 2000). Citing the last ten year average, wheat acreage varies from 7.5 to $8.5 \mathrm{mil}$ ha and the annual production varies from 17.2 to 22.6 mil tons (TMO, 2016). 14.3\% of total bread wheat production was met by southeastern Anatolia in 2016. Khapra beetle damage can reach high infestation levels in the region (Işıkber et al., 2014) and may vary from $10 \%$ (Ekmekçi and Ferizli, 2000) to 25-35\% (Kalkan,1963). Weight loss in durum wheat for an 8 months storage period was $4.075 \%$ with a 103 USD ton ${ }^{-1}$ marketing price loss (Özberk et al., 2017). Downgrading factors mostly referred by purchasers in local commodity market are the presence of sunn pest damaged grains $(\%)$, barley grain contaminations (\%), protein (\%), energy value (Joule) and sedimentation $(\mathrm{ml})$, thousands kernel weight $(\mathrm{g})$ and hectoliter weight $(\mathrm{kg})$ (Macca and Özberk, 2012; Özberk et al., 2005). Impact of khapra beetle deteriorated grains onto marketing price has not been assessed systematically in bread wheat. This study aimed to assess some physical traits, quality and marketing price of khapra beetle damaged grains under increasing larval infestations and various genotypes.

\section{Material and methods}

This laboratory experiment was carried out between 22 November 2017 and 29 April 2018 in the laboratory of department of field crops of Faculty of Agriculture in the University of Harran in Sanliurfa in Turkey. Ten advanced lines (Entry numbers of 2, 3, 4, 5, 6, 7, 8, 9, 10 and 13) from $35^{\text {th }}$ ESWYT (Elite Selection Wheat Yield Trial) 201415 (Table 4) were tested employing a split plot experimental design with three replications where larval infestation rates, i.e. 5, 10 and 15 and entries were assigned as main and subplots respectively. Losses in TKWs (g) (Uluoz, 1965), hectoliter weight $(\mathrm{kg})$, sample weight $(\mathrm{g})$ and marketing prices (cents $\mathrm{kg}^{-1}$ ) were scored at 11.01.2018, 16.02.2018 and 29.03.2018 respectively. Except for marketing price scoring, all rest of experimental material (90 jars) was subjected to above analysis. At above given dates, first replication of experiment (30 jars) were presented to randomly selected 4 purchasers in local commodity market (as replications) for marketing price estimations holding on split plot experimental design. Initial marketing price estimations of all entries with non-damage grains were scored by presenting randomly selected 4 purchasers at the same commodity market employing randomized complete block design with 4 replications (purchasers). Some of grain quality analysis of entries at the beginning such as TKW (g) (Uluoz,1965), HLW (kg) (AACC 2000 method 55-10), protein (\%) (AACC 2000 method 46-10.01), wet gluten (\%) (AACC 2000 method 3812.02), dry gluten (g) (AACC 2000 method 38-12.02), gluten index (\%) (AACC 2000 method 38-12.02), grain hardness $\left(\mathrm{kg} \mathrm{m}^{-2}\right)(\mathrm{AGW})$ and sedimentation (ml) (AACC 2000 
method 38-10.01) were both scored at the beginning and at the end of study and a paired ' $t$ ' test was performed for statistical significance. Geometric means of weight loss and marketing price reductions due to increasing khapra beetle damage were calculated and rank stability performance of entries for weight loss and marketing price punishments were scored and graphical illustrations were drawn (Huen, 1990). JMP-5 statistical software was used for all types of analyses including graphics.

\section{Implementations for laboratory trial}

Larvae were grown in corn a month prior to study start day. Grain samples were subjected to high temperature ( 5 hours at $45{ }^{\circ} \mathrm{C}$ ) to omit the possibility of early infestations. Relative humidity $(\mathrm{RH})(\%)$ after heat treatment was $10 \%$ for all experimental material. Nine samples (100 g grain in each) of healthy grains from each entry were placed into $250 \mathrm{~mL}$ glass jars. Then jars were covered by muslin cloth with rubber bunds. 5, 10 and 15 neonate khapra beetle larvae were put into 3 jars of each entry (replications). Jars were placed into incubator calibrated to $32 \pm 2{ }^{\circ} \mathrm{C}$ and $55 \pm 5 \%$ $\mathrm{RH}$ for 120 days. Damaging grains in each jar were subjected to sieving to isolate the grains dust and other residues prior to scoring for various traits. All larvae and pupae in jars were kept alive and returned to jars after scoring traits.

\section{Results}

\section{Thousands kernel weights, hectoliter weights, sample weights and marketing prices}

Above given characteristics for all entries were scored at the three consecutive dates of study. A split plot ANOVA for all traits was performed individually and the statistically significant components of variation excluding larval intensity $\mathrm{x}$ entries interactions were grouped through LSD (Least significant differences). Joint effects of major factors may result in complications in interpretations. Therefore this was avoided. Grain samples of all entries free from Khapra damage were presented to local purchasers for initial marketing price estimates and purchasers (replications) were nonsignificant $\left(\mathrm{F}=3.13^{\mathrm{ns}} \mathrm{p}>0.05\right)$. Entries were found to be significant $(\mathrm{F}=3.38 * *$ $\mathrm{p}<0.01)$. Entries 8, 3 and 2 were at top three ranks giving 30.893, 30.806 and 30.675 cents $\mathrm{kg}^{-1}$ respectively. Average marketing price of all entries was 30.50 cents kg $\mathrm{kg}^{-1}$.

\section{First scoring date (10.01.2018)}

Individual analysis of variance revealed that the response of entries against khapra beetle infestation for TKW, sample weights and marketing price were statistically significant giving $\mathrm{F}=77.36^{* * *}(\mathrm{p}<0.001), \mathrm{F}=3.829 * *(\mathrm{p}<0.01), \mathrm{F}=16.97 * *$ $(\mathrm{p}<0.01)$ respectively (Table 1$)$. No significant differences were found among larval infestation levels for TKW, HLW and sample weights. But this turned out to be significant for marketing price $\left(\mathrm{F}=46.05^{* * *}, \mathrm{p}<0.001\right)$. Except HLW, CV's (\%) for above given characteristics seemed to be reliable giving low values. A $13.28 \% \mathrm{CV}$ for HLW was found to be higher than expected one. The means of statistically significant entries for TKW, sample weights and marketing price were grouped by LSD test. Entry number of 6, 8 and 7 ranked at top three giving 49.238, 44.988 and $44.539 \mathrm{~g}$ of TKW values. Entry numbers of 6, 8 and 10 for sample weight ranked at first three presenting none weight losses. Entry numbers of 3, 9, and 4 for marketing price placed at the first 
three ranks giving 27.530, 27.504 and 27.496 cents $\mathrm{kg}^{-1}$ respectively. Larval infestations of 5, 10 and 15 for same characteristics gave 27.632, 26.965 and 26.376 cents kg as $^{-1}$ expected.

Table 1. Means and LSD groups of varieties and larval infestation levels for the TKW, $H L W$, weight loss and marketing price from $100 \mathrm{~g}$ of initial sample weight in first scoring date (10.01.2018)

\begin{tabular}{|c|c|c|c|c|c|c|c|}
\hline $\begin{array}{c}\text { Entry } \\
\text { number }\end{array}$ & $\begin{array}{c}\text { TKW } \\
\text { (g/groups) }\end{array}$ & $\begin{array}{c}\text { Entry } \\
\text { number }\end{array}$ & $\begin{array}{c}\text { HLW } \\
\text { (kg/groups) }\end{array}$ & $\begin{array}{c}\text { Entry } \\
\text { number }\end{array}$ & $\begin{array}{c}\text { Sample } \\
\text { weight } \\
\text { (g/groups) }\end{array}$ & $\begin{array}{c}\text { Entry } \\
\text { number }\end{array}$ & $\begin{array}{l}\text { Marketing price } \\
\text { (cent/kg/groups) }\end{array}$ \\
\hline 6 & $49.238 a$ & 3 & 82.40 & 6 & 100.0 & 3 & $27.530 \mathrm{a}$ \\
\hline 8 & $44.988 \mathrm{~b}$ & 7 & 81.97 & 8 & 100.0 & 9 & $27.504 \mathrm{a}$ \\
\hline 7 & $44.537 \mathrm{~b}$ & 9 & 81.08 & 10 & 100.0 & 4 & $27.496 \mathrm{a}$ \\
\hline 9 & $44.228 b c$ & 1 & 80.51 & 9 & 99.99 & 1 & $27.268 \mathrm{a}$ \\
\hline 10 & $43.498 \mathrm{c}$ & 4 & 80.37 & 5 & 99.98 & 6 & $27.236 \mathrm{ab}$ \\
\hline 3 & $42.096 \mathrm{~d}$ & 10 & 80.25 & 4 & 99.95 & 10 & $27.235 \mathrm{ab}$ \\
\hline 4 & $40.874 \mathrm{e}$ & 2 & 79.87 & 3 & 99.88 & 7 & $27.197 \mathrm{ab}$ \\
\hline 2 & 40.341ef & 6 & 79.10 & 2 & 99.84 & 5 & $26.885 \mathrm{~b}$ \\
\hline 5 & $39.674 \mathrm{fg}$ & 8 & 78.75 & 7 & 99.84 & 8 & $26.375 \mathrm{c}$ \\
\hline 1 & $38.993 \mathrm{~g}$ & 5 & 75.05 & 1 & 99.66 & 2 & $25.847 \mathrm{~d}$ \\
\hline \multicolumn{8}{|c|}{ Larval intensity } \\
\hline 5 & 43.133 & 10 & 81.27 & 5 & 99.99 & 5 & $27.632 \mathrm{a}$ \\
\hline 15 & 42.763 & 5 & 81.11 & 10 & 99.89 & 10 & $26.965 \mathrm{~b}$ \\
\hline 10 & 42.645 & 15 & 77.44 & 15 & 99.85 & 15 & $26.576 \mathrm{c}$ \\
\hline \multicolumn{8}{|c|}{ Statistical significances for some sources of variation and some descriptive statistics } \\
\hline F entries & $77.36 * *$ & & $0.57^{\mathrm{ns}}$ & & $3.829 * *$ & & $16.97 * *$ \\
\hline F larval intensity & $1.74^{\mathrm{ns}}$ & & $2.14^{\text {ns }}$ & & $0.07^{\mathrm{ns}}$ & & $46.05^{* *}$ \\
\hline Grand mean & 42.84 & & 79.94 & & 99.917 & & 27.057 \\
\hline Std. deviation & 1.056 & & 8.118 & & 0.168 & & 0.46 \\
\hline LSD entries & 1.728 & & 13.28 & & 0.278 & & 0.644 \\
\hline LSD larval intensity & na & & na & & na & & 0.324 \\
\hline CV\% & 2.46 & & 10.01 & & 0.168 & & 1.70 \\
\hline
\end{tabular}

na: not available, ns: not significant, $* \mathrm{p}<0.05, * * \mathrm{p}<0.01$

\section{Second scoring date (16.02.2018)}

Individual analyses of variances (Table 2) were also performed for same traits given above. $\mathrm{F}_{\text {entries }}$ turned out to be significant for all characteristics giving $\mathrm{F}=53.57 * * *$ $(\mathrm{p}<0.001), \mathrm{F}=5.87 * *(\mathrm{p}<0.01), \mathrm{F}=3.02 * *(\mathrm{p}<0.01)$ and $\mathrm{F}=19.98 * *(\mathrm{p}<0.01)$ respectively. $\mathrm{F}$ values for larval infestation levels for all traits also turned out to be significant giving $\mathrm{F}=20.94 * *(\mathrm{p}<0.01), \quad \mathrm{F}=45.75^{* * *}(\mathrm{p}<0.001), \quad \mathrm{F}=28.55^{* *}$ $(\mathrm{p}<0.01)$ and $\mathrm{F}=102.53 * * *(\mathrm{p}<0.001)$ respectively. CV's $(\%)$ for all traits under study were also quite low presenting reliability of the results. Entry numbers of 6,8 and 9 for TKW ranked at top three giving $48.24,43.53$ and $43.50 \mathrm{~g}$ respectively. For HLW, entry numbers of 9,5 and 4 placed at the first three ranks with $81.12,81.06$ and $80.95 \mathrm{~kg}$ respectively. For the sample weight, entry numbers of 10,9 and 6 were the first three ranking entries with $99.08,99.06$ and $98.53 \mathrm{~g}$ presenting to be the least 
affected genotypes from khapra beetle infestation. For the marketing price estimates, entry numbers of 1, 9 and 3 were the higher marketing price offer receiving genotypes with $26.910,26.779$ and 26.354 cents $\mathrm{Kg}^{-1}$ respectively. When the larval intensity increased from 5 to 15 , TKW declined from 42.47 to $40.10 \mathrm{~g}$, HLW from 81.62 to $78.25 \mathrm{~kg}$, sample weight from 98.97 to $96.918 \mathrm{~g}$ and marketing price from 26.918 to 25.389 cents $\mathrm{kg}^{-1}$.

Table 2. Means and LS D groups of varieties and larval infestation levels for the TKW, $H L W$, weight loss and marketing price from $100 \mathrm{~g}$ of initial sample weight in second scoring date (16.02.2018)

\begin{tabular}{|c|c|c|c|c|c|c|c|}
\hline $\begin{array}{c}\text { Entry } \\
\text { number }\end{array}$ & $\begin{array}{c}\text { TKW } \\
\text { (g/groups) }\end{array}$ & $\begin{array}{c}\text { Entry } \\
\text { number }\end{array}$ & $\underset{\text { (kg/groups) }}{\text { HLW }}$ & $\begin{array}{c}\text { Entry } \\
\text { number }\end{array}$ & $\begin{array}{c}\text { Sample } \\
\text { weight } \\
\text { (g/groups) }\end{array}$ & $\begin{array}{c}\text { Entry } \\
\text { number }\end{array}$ & $\begin{array}{l}\text { Marketing price } \\
\text { (cent/kg/groups) }\end{array}$ \\
\hline 6 & $48.24 \mathrm{a}$ & 9 & $81.12 \mathrm{a}$ & 10 & $99.08 \mathrm{a}$ & 1 & $26.910 \mathrm{a}$ \\
\hline 8 & $43.53 b$ & 5 & $81.06 \mathrm{a}$ & 9 & $99.06 \mathrm{a}$ & 9 & $26.779 a$ \\
\hline 9 & $43.50 \mathrm{~b}$ & 4 & $80.95 \mathrm{a}$ & 6 & $98.53 \mathrm{ab}$ & 3 & $26.354 \mathrm{~b}$ \\
\hline 7 & $43.46 \mathrm{~b}$ & 1 & $80.94 a$ & 8 & $98.35 \mathrm{ab}$ & 6 & $26.215 b c$ \\
\hline 10 & $40.44 c$ & 3 & $80.43 \mathrm{ab}$ & 2 & $98.06 \mathrm{abc}$ & 10 & $26.177 b c$ \\
\hline 3 & $40.18 \mathrm{c}$ & 10 & $80.34 \mathrm{ab}$ & 4 & $97.87 \mathrm{bc}$ & 4 & $26.154 \mathrm{bc}$ \\
\hline 4 & $39.55 \mathrm{~cd}$ & 2 & $80.13 \mathrm{ab}$ & 5 & $97.81 \mathrm{bc}$ & 2 & $26.000 \mathrm{c}$ \\
\hline 5 & $38.67 \mathrm{de}$ & 7 & $80.05 \mathrm{ab}$ & 3 & $97.66 \mathrm{bc}$ & 7 & $25.687 \mathrm{~d}$ \\
\hline 2 & $37.89 \mathrm{e}$ & 6 & $79.40 \mathrm{~b}$ & 7 & $97.51 b c$ & 8 & $25.667 d$ \\
\hline 1 & $36.38 \mathrm{f}$ & 8 & $77.35 \mathrm{c}$ & 1 & $97.18 \mathrm{c}$ & 5 & $25.380 \mathrm{e}$ \\
\hline \multicolumn{8}{|c|}{ Larval intensity } \\
\hline 5 & $42.47 \mathrm{a}$ & 5 & $81.62 \mathrm{a}$ & 5 & $98.97 \mathrm{a}$ & 5 & $26.918 \mathrm{a}$ \\
\hline 10 & $4098 b$ & 10 & $80.66 a$ & 10 & $98.45 \mathrm{a}$ & 10 & $26.095 b$ \\
\hline 15 & $40.10 \mathrm{c}$ & 15 & $78.25 \mathrm{~b}$ & 15 & $96.91 \mathrm{~b}$ & 15 & $25.389 \mathrm{c}$ \\
\hline \multicolumn{8}{|c|}{ Statistical significances for some sources of variation and some descriptive statistics } \\
\hline F entries & $53.57 * *$ & & $5.87 * *$ & & $3.02 * *$ & & $19.98 * *$ \\
\hline F larval intention & $20.94 * *$ & & $45.75^{* *}$ & & $28.55^{* *}$ & & $102.53 * *$ \\
\hline G. mean & 41.188 & & 80.18 & & 98.11 & & 26.134 \\
\hline Std. deviation & 1.43 & & 1.40 & & 1.098 & & 0.37 \\
\hline LSD entries & 2.34 & & 2.26 & & 1.79 & & 0.626 \\
\hline LSD larval int. & na & & 3.18 & & 2.49 & & 0.510 \\
\hline $\mathrm{CV} \%$ & 3.47 & & 1.74 & & 1.11 & & 1.41 \\
\hline
\end{tabular}

na: not available, ns: not significant, ${ }^{*} \mathrm{p}<0.05, * * \mathrm{p}<0.01$

\section{Third scoring date (29.03.2018)}

Analysis of variance for each traits was performed (Table 3) and $\mathrm{F}_{\text {entries }}$ and $\mathrm{F}_{\text {larval }}$ intensities were all found to be significant giving either $\mathrm{p}<0.01$ or $\mathrm{p}<0.001$ significance. CV's (\%) obtained from ANOVA's ranging from 1.307 to $3.47 \%$ indicated the reliability of the results. Entry numbers of 6,9 and 8 were the first three ranking genotypes giving 46.66, 43.59 and $43.31 \mathrm{~g}$ of TKW's respectively. For the hectoliter weight, entries 5, 6 and 9 were the highest ranking entries giving 81.72, 81.19 and 80.03 $\mathrm{kg}$ respectively. For the sample weight, entry numbers of 9,6 and 10 were the top ranking and least affected genotypes with $98.30,98.28$ and $97.86 \mathrm{~g}$ respectively. Finally 
in marketing price, entries 9, 1 and 10 were found to be less affected genotypes from khapra beetle infestation giving 25.755, 24.792 and 24.450 cents $\mathrm{kg}^{-1}$ respectively. As the larval intensity increased from 5 to 15 , TKW decreased from 42.95 to $39.43 \mathrm{~g}$, HLW from 81.14 to $77.26 \mathrm{~kg}$, sample weight from 98.68 to $94.18 \mathrm{~g}$ and marketing price from 25.542 to 22.803 cents $\mathrm{kg}^{-1}$ respectively.

Table 3. Means and LS D groups of varieties and larval infestation levels for the TKW, $H L W$, weight loss and marketing price from $100 \mathrm{~g}$ of initial sample weight in second scoring date (29.03.2018)

\begin{tabular}{|c|c|c|c|c|c|c|c|}
\hline Entry number & $\begin{array}{c}\text { TKW } \\
\text { (g/groups) }\end{array}$ & $\begin{array}{c}\text { Entry } \\
\text { number }\end{array}$ & $\begin{array}{c}\text { HLW } \\
\text { (kg/groups) }\end{array}$ & $\begin{array}{c}\text { Entry } \\
\text { number }\end{array}$ & \begin{tabular}{|c|} 
Sample \\
weight \\
(g/groups)
\end{tabular} & $\begin{array}{c}\text { Entry } \\
\text { number }\end{array}$ & $\begin{array}{l}\text { Marketing price } \\
\text { (cent/kg/groups) }\end{array}$ \\
\hline 6 & $46.66 \mathrm{a}$ & 5 & $81.72 \mathrm{a}$ & 9 & $98.30 \mathrm{a}$ & 9 & $25.755 a$ \\
\hline 9 & $43.59 b$ & 6 & $81.19 \mathrm{ab}$ & 6 & $98.28 \mathrm{a}$ & 1 & $24.792 b$ \\
\hline 8 & $43.31 b$ & 9 & $80.03 \mathrm{ab}$ & 10 & $97.86 \mathrm{ab}$ & 10 & $24.450 \mathrm{c}$ \\
\hline 7 & $42.75 b$ & 1 & $79.89 \mathrm{ab}$ & 2 & $97.08 \mathrm{abc}$ & 7 & $24.039 \mathrm{~d}$ \\
\hline 10 & $41.31 \mathrm{c}$ & 3 & $79.77 \mathrm{ab}$ & 5 & $96.57 \mathrm{bcd}$ & 4 & $23.950 \mathrm{de}$ \\
\hline 3 & $39.38 \mathrm{~cd}$ & 2 & $79.57 \mathrm{ab}$ & 8 & $96.23 \mathrm{~cd}$ & 6 & $23.948 \mathrm{de}$ \\
\hline 2 & $39.55 \mathrm{de}$ & 7 & $79.53 \mathrm{ab}$ & 3 & $96.06 \mathrm{~cd}$ & 3 & $23.804 \mathrm{de}$ \\
\hline 4 & $39.47 \mathrm{de}$ & 4 & $78.88 b$ & 4 & $95.93 \mathrm{~cd}$ & 2 & $23.762 \mathrm{e}$ \\
\hline 5 & $38.42 \mathrm{e}$ & 10 & $78.83 b$ & 7 & $95.76 \mathrm{~cd}$ & 8 & $23.447 f$ \\
\hline 1 & $37.39 \mathrm{f}$ & 8 & $77.08 \mathrm{c}$ & 1 & $95.19 \mathrm{~d}$ & 5 & $22.960 \mathrm{~g}$ \\
\hline \multicolumn{8}{|c|}{ Larval intensity } \\
\hline 5 & $42.95 a$ & & $81.14 \mathrm{a}$ & & $98.68 \mathrm{a}$ & & $25.542 \mathrm{a}$ \\
\hline 10 & $41.34 b$ & & $79.95 a$ & & $97.32 b$ & & $23.927 b$ \\
\hline 15 & $39.43 c$ & & $77.26 \mathrm{~b}$ & & $94.18 \mathrm{c}$ & & $22.803 \mathrm{c}$ \\
\hline \multicolumn{8}{|c|}{ Statistical significances for some sources of variation and some descriptive statistics } \\
\hline F entries & $34.99 * *$ & & $2.71 * *$ & & $3.80 * *$ & & $71.00 * *$ \\
\hline F larval intensity & $45.45^{* *}$ & & $35.49 * *$ & & $55.41 * *$ & & $387.9 * *$ \\
\hline G. mean & 41.246 & & 79.45 & & 96.73 & & 24.09 \\
\hline Std. deviation & 1.432 & & 1.83 & & 1.697 & & 0.315 \\
\hline LSD entries & 2.345 & & 2.995 & & 2.778 & & 0.442 \\
\hline LSD larval int. & 3.247 & & 4.148 & & 3.848 & & 0.534 \\
\hline $\mathrm{CV} \%$ & 3.47 & & 2.30 & & 1.75 & & 1.307 \\
\hline
\end{tabular}

na: not available, ns: not significant, $* \mathrm{p}<0.05, * * \mathrm{p}<0.01$

\section{Comparison of initial and final quality parameters}

Some of the major quality traits of all entries scored as the average of three reads at the beginning and at the end of study were given in Table 4. For the final quality analysis, all three replicates of each infestation level were joined prior to analyzing quality. Statistical significance between grand means of various characteristics at the beginning and at the end of study was investigated through paired ' $t$ ' test. Except grain hardness, grand mean differences for all scored traits were found to be significant. Final means were always lower than those of initials. In grain hardness, non-damaged kernels were employed for scoring both at the beginning and at the end of study. Final grand means for TKW (g), HLW (kg), protein content $(\%)$, wet gluten $(\%)$, dry gluten $(\mathrm{g})$, gluten index (5) and sedimentation ( $\mathrm{ml}$ ) were significantly lower than those of initials. 
Table 4. Comparison of some of quality characteristics scored initially and at the end of study

\begin{tabular}{|c|c|c|c|c|c|c|c|c|c|}
\hline $\begin{array}{c}\text { Entry } \\
\text { number } \\
\text { (initial) }\end{array}$ & $\begin{array}{c}\text { Orijin } \\
\text { ESWYT 2014-15 }\end{array}$ & $\begin{array}{c}\text { TKW } \\
\text { (g) }\end{array}$ & $\begin{array}{c}\text { HLW } \\
(\mathbf{k g})\end{array}$ & $\begin{array}{c}\text { Protein } \\
(\%)\end{array}$ & $\begin{array}{c}\text { Wet } \\
\text { gluten } \\
(\%)\end{array}$ & $\begin{array}{c}\text { Dry } \\
\text { gluten } \\
(\mathrm{g})\end{array}$ & $\begin{array}{c}\text { Gluten } \\
\text { index } \\
(\%)\end{array}$ & $\begin{array}{c}\text { Grain } \\
\text { hardness } \\
(\mathbf{k g})\end{array}$ & $\begin{array}{c}\text { Sedimentation } \\
(\mathrm{ml})\end{array}$ \\
\hline 1 & $\operatorname{Prl} / 2 * *$ Pastor & 38.48 & 80.94 & 12.40 & 37.9 & 1.23 & 89.0 & 12.62 & 43 \\
\hline 2 & Kachu\#1 & 44.63 & 81.69 & 12.60 & 34.5 & 1.15 & 95.2 & 13.51 & 39 \\
\hline 3 & Misr 1 & 41.86 & 82.30 & 12.90 & 38.3 & 1.29 & 94.1 & 12.88 & 46 \\
\hline 4 & Munal\#1 & 41.51 & 80.63 & 11.00 & 32.2 & 1.08 & 97.0 & 10.91 & 49 \\
\hline 5 & Bekard\#1/5/Kritati/4/.. & 41.20 & 81.99 & 10.50 & 31.0 & 1.06 & 92.1 & 10.34 & 34 \\
\hline 6 & Becard/Chyak & 48.97 & 80.67 & 12.10 & 38.2 & 1.24 & 8105 & 10.70 & 39 \\
\hline 7 & Taita & 45.55 & 80.88 & 11.40 & 30.7 & 1.08 & 98.4 & 10.67 & 37 \\
\hline 8 & Kachu//Kritati/2*TRCH & 44.59 & 77.22 & 11.60 & 25.4 & 0.91 & 98.2 & 8.39 & 35 \\
\hline 9 & Kachu/Chonte & 40.47 & 81.97 & 12.70 & 35.2 & 1.19 & 97.6 & 9.36 & 44 \\
\hline 10 & Kritati/Huw234+LR34/Prinia.. & 40.64 & 80.33 & 12.40 & 37.8 & 1.24 & 96.0 & 10.88 & 49 \\
\hline $\begin{array}{c}\text { Entry } \\
\text { number } \\
\text { (final) }\end{array}$ & $\begin{array}{c}\text { Orijin } \\
\text { ESWYT 2014-15 }\end{array}$ & $\underset{(\mathrm{g})}{\mathbf{T K W}}$ & $\begin{array}{c}\text { HLW } \\
(\mathbf{K g})\end{array}$ & $\begin{array}{c}\text { Protein } \\
(\%)\end{array}$ & $\begin{array}{c}\text { Wet } \\
\text { gluten } \\
(\%)\end{array}$ & $\begin{array}{c}\text { Dry } \\
\text { gluten } \\
(\mathrm{g})\end{array}$ & $\begin{array}{c}\text { Gluten } \\
\text { index } \\
(\%)\end{array}$ & $\begin{array}{c}\text { Grain } \\
\text { hardness } \\
(\mathrm{Kg})\end{array}$ & $\begin{array}{c}\text { Sedimentation } \\
(\mathrm{ml})\end{array}$ \\
\hline 1 & $\operatorname{Prl} / 2 * *$ Pastor & 37.70 & 79.90 & 13.24 & 36.8 & 1.22 & 85.0 & 10.51 & 37 \\
\hline 2 & Kachu\#1 & 39.55 & 79.48 & 12.28 & 31.9 & 1.10 & 95.5 & 10.95 & 37 \\
\hline 3 & Misr 1 & 39.98 & 79.77 & 13.40 & 37.8 & 1.05 & 87.4 & 11.57 & 40 \\
\hline 4 & Munal\#1 & 39.27 & 78.88 & 11.65 & 29.6 & 1.05 & 98.3 & 11.82 & 42 \\
\hline 5 & Bekard\#1/5/Kritati/4/.. & 38.42 & 80.72 & 10.60 & 30.8 & 1.01 & 87.2 & 10.35 & 32 \\
\hline 6 & Becard/Chyak & 46.66 & 80.19 & 13.08 & 35.4 & 1.23 & 76.5 & 10.42 & 36 \\
\hline 7 & Taita & 41.74 & 79.53 & 11.00 & 32.3 & 1.04 & 88.1 & 10.85 & 36 \\
\hline 8 & $\mathrm{Kachu} / /$ Kritati/2*TRCH & 43.31 & 77.55 & 10.20 & 26.4 & 0.86 & 98.8 & 9.79 & 31 \\
\hline 9 & Kachu/Chonte & 40.49 & 80.03 & 12.20 & 32.5 & 1.14 & 95.1 & 7.77 & 41 \\
\hline 10 & Kritati/Huw234+LR34/Prinia.. & 41.31 & 78.83 & 11.80 & 32.1 & 1.08 & 77.8 & 10.81 & 47 \\
\hline $\begin{array}{c}\text { Mean } \\
\text { (initial) }\end{array}$ & & 42.79 & 80.91 & 11.96 & 34.12 & 1.147 & 93.86 & 11.026 & 41.5 \\
\hline Mean (final) & & 40.85 & 79.56 & 11.94 & 32.56 & 1.078 & 88.97 & 10.48 & 37.9 \\
\hline $\begin{array}{c}\text { Paired } \\
\text { student t } \\
\text { /significance }\end{array}$ & & 3.08* & $5.04 * *$ & $\mathbf{0 . 0 8 3}^{\text {ns }}$ & $2.75^{*}$ & 3.00* & $2.60 *$ & $1.903^{\mathrm{ns}}$ & $5.523 * *$ \\
\hline
\end{tabular}

na: not available, ns: not significant, ${ }^{*} \mathrm{p}<0.05,{ }^{* *} \mathrm{p}<0.01$

\section{Ranks stability analysis for sample weight and marketing price}

A rank stability analysis for sample weight (Fig. 1) and marketing price (Fig. 2) was performed employing average rank and rank standard deviations of all entries. Entry numbers of $6,10,9$ and 8 were the least weight loosing genotypes. Especially entry number of 6 had also lower standard deviation than grand mean of all standard deviations. Entry numbers of 9, 1, 3 and 10 were the highest marketing price offer receiving genotypes respectively. Entry numbers of 9, 1 and 10 were also found to be more stable than that of 3 with relatively lower standard deviation than that of grand mean of all entries. Geometric mean of weight loss during 120 days was $8 \mathrm{~kg} \mathrm{ton}^{-1}$ and the loss was $32.7 \mathrm{~kg} \mathrm{ton}^{-1}$ at the final scoring date. Ceiling marketing prices and grands mean of marketing prices of all entries at the scoring dates were given in Figure 3. Taking into account initial and final marketing prices and excluding parity loss of Turkish Lira against US Dollar, a 30.08 USD ton $^{-1}$ genuine marketing price loss was detected for 120 days. 


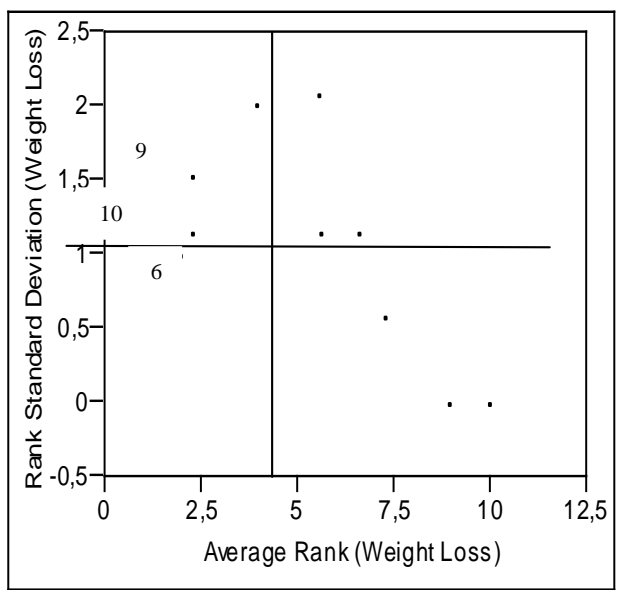

Figure 1. Rank stability analysis for weight loss of entries

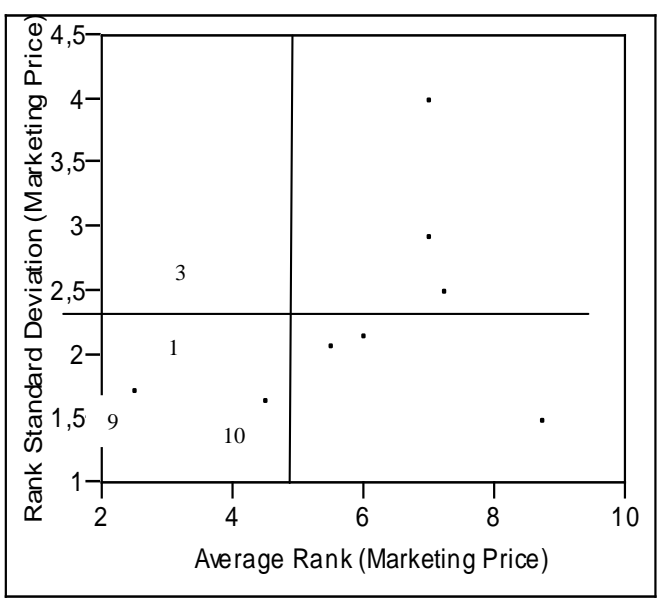

Figure 2. Rank stability analysis for marketing price of entries

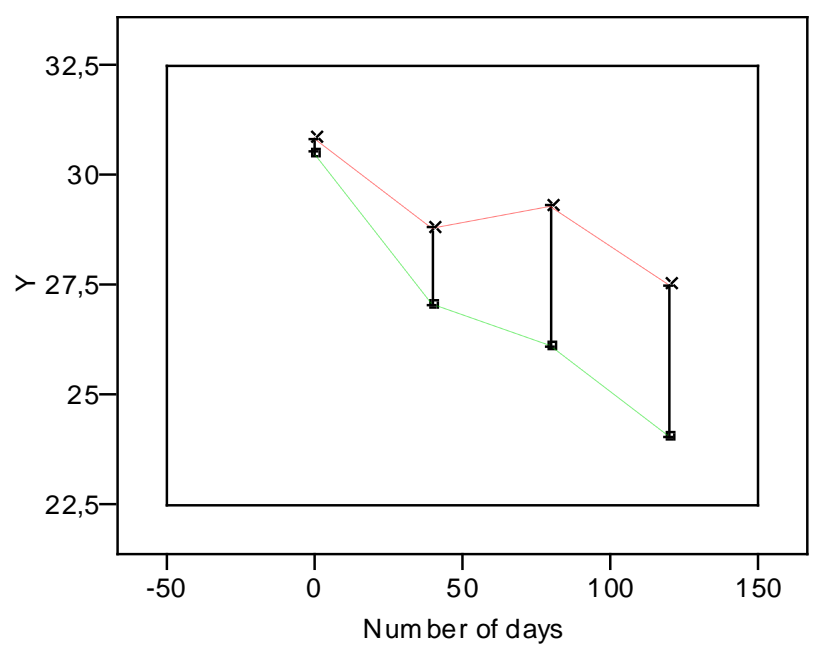

Y $\mathbf{x}-$ Ceiling Price (Cent $/ K g)$

- Average marketing price (Khapra damaging) (Cent/Kg) gr:

Figure 3. Differences between ceiling prices and current marketing prices of entries at the beginning and at the consecutive dates of scoring (0,40,80 and 120 days) 


\section{Discussion}

Apart from initial and final scoring, TKW and HLW were scored regularly during the course of study. There was only $1.544 \mathrm{~g}$ reduction between grand means of all entries at the beginning (42.79 g) and that of at the end (41.246 g). Same trend was detected for HLW. There was only $1.46 \mathrm{~kg}$ decline at the beginning $(80.96 \mathrm{~kg})$ and at the end of study $(79.45 \mathrm{~kg}$ ). Özberk et al. (2017) obtained a $3.96 \mathrm{~g}$ reduction in TKW for 8 months in durum wheat. Weight loss of jars with $100 \mathrm{~g}$ of grain sample initially increased during the course of a 120 day period. Geometric mean of weight loss for study period was $8 \mathrm{~kg}_{\text {ton }}{ }^{-1}$ whereas at the final date, weight loss was $32.7 \mathrm{~kg} \mathrm{ton}^{-1}$ (3.27\%). Grand mean of weight loss in durum wheat was $4.075 \%$ in 8 months (Özberk et al., 2017). Varietal differences to khapra beetle infestation were detected for above given characteristics. Entry number of 6, 7, 8 and 9 for TKW and entry numbers of 6, 9 and 10 for HLW were the least affected genotypes. These results matched those of Ahmedani et al. (2009, 2011), Sayed et al. (2006) and Khattak et al. (2000). In which Mehran-89 and Wafaq-2001 were the least affected cultivars against khapra beetle infestation. Physio- chemical and biochemical structure of grains were proved to be properties for resistance mechanism (Warchalewski et al.,1993; Dobbie, 1991; Baker, 1986). The effects of larval intensities for all traits given above were significant. When the larval intensity increased, TKW, HLW and initial weight decreased confirming the results of Özberk et al. (2017), Ahmedani et al. (2011), Khattak et al. (2000) and Navarro et al. (1978). They proved the presence of high degree positive and significant correlations between progeny development vs. damage ratio and weight loss. Some of quality analysis such as wet (\%), dry gluten (g), gluten index (\%) and sedimentation $(\mathrm{ml})$ at initial stage vs. final resulted in lower values for latter significantly. For the final analysis, all replications were joined to avoid any biased estimation. Non-significant grain hardness may be due to employment of only healthy grains for both scoring. Nonsignificant protein content (\%) between initial vs. final seemed to be insect inclusion to flour and this results in some increase in protein (\%). Marketing price estimations were received from randomly selected 4 purchasers (replications) at the local commodity market employing first replication of laboratory experiment. As shown by Figure 3, ceiling prices decreased gradually toward end of study due to the parity loss of Turkish Lira against US dollar $\left(30.84-27.51=3.33\right.$ cents $\left.\mathrm{kg}^{-1}\right)$. Whereas marketing price of khapra beetle infested grains reduced from 30.50 to 24.09 cents $\mathrm{kg}^{-1}$ for 120 days. A 6.41 cents $\mathrm{kg}^{-1}$ marketing price loss can be attributed to khapra infestation and parity loss. A 3.08 cents $\mathrm{kg}^{-1}$ marketing price loss (6.41- 3.33 cents $\mathrm{kg}^{-1}$ ) was genuine due to khapra damage. This means a 30.8 USD ton $^{-1}$ marketing price loss for 120 days. This was a 103 USD ton $^{-1}$ for durum wheat in 8 months (Özberk et al., 2017).

Varietal differences to khapra beetle attack were genuine and entry numbers of 9,1 , 3 and 10 were the least marketing price loosing and stable genotypes. Increasing larval intensity reduced marketing price as detected by Özberk et al. (2017) in durum wheat. Economic loss of grain grower countries suffering Khapra beetle damage seem to be huge (Sayed et al., 2006; Ahmedani et al., 2007; Özberk et al., 2017). Hence, taking into account for zero tolerance trends of some countries such as Canada (Canada Grain Act, 1975) to stored grain insects, control measures and resistance mechanism of grains against Khapra beetle must be the focused of such researches. 


\section{Conclusions}

It was concluded that even a short duration of storage such as 120 days, khapra beetle affected all quality parameters negatively and resulted in as much as $3.27 \%$ weight loss and a 30.8 USD ton $^{-1}$ marketing price loss. The presence of varietal response to khapra beetle attack should also be stressed.

Acknowledgements. Many thanks for the purchasers (M. Satıs, B. Koc, H. Aslan, O. Gok, H. Salgu) in local commodity market for their help in marketing price estimates, K. Ayıkgoz for quality analysis and marketing price scoring, H. Ayhan for grain hardness analysis, D. Izol for larvae development, incubation and scoring. I declare my deep respects to I. Ozberk for his encouragement, comments, critics and helps for statistical analysis and $\mathrm{M} / \mathrm{s}$ preparation.

\section{REFERENCES}

[1] AACC (2000): Approved methods of the American Association of Cereal Chemists.10th ed. - The American Association of Cereal Chemists, Approved Methods Committee, St. Paul, MN, USA.

[2] Ahmad, H. (1984): Storage of wheat in Pakistan. - Progressive Farming (Pakistan) 4(4): 36-40.

[3] Ahmad, M., Khan, M. R., Iqbal, A., Hassan, M. (1986): Farm level storage loss of wheat by insect pests in Samundri Tehsil. - Pakistan Entomology 8: 41-44.

[4] Ahmedani, M. S., Khaliq, A., Tarıq, M., Anwar, M., Naz, S. (2007): Khapra beetle (Tragoderma granarium Everts): A serious threat to food security and safety. - Pakistan Journal of Agricultural Science 44(3): 481-487.

[5] Ahmedani, M. S., Haque, M. I., Afzal, S. N., Aslam, M., Naz, S. (2009): Varietal changes in nutritional composition of wheat kernel (Triticum aestivum L.) caused by Khapra beetle infestation. - Pakistan Journal of Botany 41(3): 1511-1519.

[6] Ahmedani, M. S., Haque, M. I., Afzal, S. N., Naeem, M., Hussain, T., Naz, S. (2011): Quantitative losses and physical damage caused to wheat kernel (Triticum aestivum L.) by khapra beetle infestation. - Pakistan Journal of Botany 43(1): 659-668.

[7] Anonymous (2005): Industry Biosecurity Plan for the Grains Industry. Threat-Specific Contingency Plan 2005. - Department of Agriculture, Bentley Delivery Centre, WA, Australia.

[8] Baker, J. E. (1986): Amylase/proteinase ratios in larval midgets of ten stored product insects. - Entomol. Exp. Appl. 40: 41-46.

[9] Canada Grain Act. (1975): Canada grain regulations. - Canada Gazette, Part II 109(14): 1708-1839.

[10] Chaudhry, M. A. (1980): Aggregate Post-harvest Food Grain Losses in Pakistan, Vol. VI. - Dept. Agric. Marketing, UAF., Faisalabad.

[11] Dobie, P. (1991): Host-Plant Resistance to Insects in Stored Cereals and Legumes. - In: Gorham, J. R., Arlington, V. A. (eds.) Ecology and Management of Food-Industry Pests. AOAC, Rochville, Maryland, pp. 373-383.

[12] Ekmekçi, M. A., Ferizli, G. (2000): Current status of stored products protection in Turkey. - Integrated Protection of Stored Products IOBC Bulletin 23: 39-46.

[13] FAO Stat (2009): http://faostat.fao.org. - Accessed on 08.10.2014.

[14] Girish, G. K., Kumar, A., Jain, S. K. (1975): Assessment of the quality loss in wheat damaged by Tragorderma granarium Everts during storage. - Bulletin of Grain Technology 13(1): 26-32. 
[15] Huehn, M. (1990): Non-parametric Estimation and Testing of g x e Interactions by Rank. - In: Manjit, S. K. (ed). Genotype and Environment Interactions and Plant Breeding. Dept. of Agriculture, Lousiana State Univ., USA, pp. 69-94.

[16] Huque, H., Anwar, M. S., Anisa, B. (1969): Control of khapra beetle in larval stage by the use of Malathion. - Agriculture Pakistan 20: 279-286.

[17] Irshad, M., Baloch, U. K. (1985): Losses in wheat during storage and their prevention. Progressive Farming (Pakistan) 5(2): 17-79.

[18] Işıkber, A. A., Er, M. K., Tunaz. H., Bozkurt, H., Aydın, Z., Eroğlu, S. (2014): The occurrence and abundance of insect pests infesting stored wheat grains in different climatic zones of Turkey. - Proceedings of the 11th International Working Conference on Stored Product Protection (24-28 November 2014, Chiang Mai, Thailand), pp. 626-630.

[19] Jood, S., Kapoor, A. C. (1993): Protein and uric acid contents of cereal grains as affected by insect infestation. - Food Chemistry 46: 143-146.

[20] Jood, S., Kapoor, A. C., Singh, R. (1993): Available carbohydrates of cereal grains as affected by storage and insect infestation. - Plant Foods and Human Nutrition 43: 45-54.

[21] Jood, S., Kapoor, A. C., Singh, R. (1996): Effect of insect infestation and storage on lipids of cereal grains. - Journal of Agriculture and Food Chemistry 44: 1502-1506.

[22] Kalkan, M. (1963): Türkiye'de Trogederma Türleri, Trogoderma granarium (Everst)' in Laboratuvarda Kısa Biyolojisi ve Mücadelesi Üzerine İncelemeler. - Tarım Bakanlığ Zirai Mücadele Enstitüsü, Ankara.

[23] Khattak, S. U., Kamal, S., Ullah, K., Ahmad, S. Khan, A. U., Jabbar, A. (2000): Appraisal of rainfed wheat lines against Khapra beetle (Trogoderma granarium Everts). Pakistan Journal of Zoology 32: 131-134.

[24] Kumar, S. K., Srivastava, C. (2017): Effect of temperature and food on the biology of Khapra beetle, tragoderma granarium Everts. - Journal of Entomology and Zoology Studies 5(3): 1015-1019.

[25] Macca, I., Özberk, I. (2012): Adıyaman ürün borsasında ekmeklik buğday fiyatlarını etkileyen faktörler. - Harran Üniversitesi Ziraat Fakültesi Dergisi 16(3): 49-59.

[26] Navarro, S., Kashanchi, Y., Green, M., Frandji, H. (1978): Causes of Loss in Stored Grain in Israel. - Progress Report, Israel Ministry of Agriculture, Israel Research Organization 1976/77.

[27] Özberk, I., Atlı, A., Pfeiffer, W., Özberk, F., Coşkun, Y. (2005): The effect of sunn pest (Eurigaster integriceps) damage on durum wheat: Impact in the market place. - Crop Protection 24(3): 267-274.

[28] Özberk, F., Özberk, I., Yücel, A. Atl1, A., Izol, D. (2017): Khapra beetle (Trogoderma granarium Everts, 1898) in durum wheat (Triticum durum Desf): Impacts on some seed characteristics and marketing price. - Turkish Journal of Entomology 41(2): 207-218.

[29] Prasad, H., Bhatia, P., Sethi, G. R. (1977): Estimation of feeding losses by Tragoderma granarium Everts in wheat. - Indian Journal of Entomology 39: 377-378.

[30] Sayed, T. S., Hirad, F. Y., Abro, G., H. (2006): Resistance of different wheat varieties to Khapra beetle, Trogoderma granarium Everts and lesser grain borer, Rhizopertha dominica (Fabricius). - Pakistan Journal of Biological Science 9: 1567-1571.

[31] TMO (2016): 2016 Y1l hububat raporu. - http://www.tmo.gov.tr. Accessed on 10.10.2017.

[32] Uluöz, M. (1965): Wheat Flour and Bread Analysis. - EUZF Pub. No: 57, Izmir, Turkey.

[33] Warchalewski, J. R., Nawrot, J. (1993): Insect infestation versus some properties of wheat grain. - Roczniki Nauk Rolniczych, Seria E. 23: 85-92.

[34] Yadav, J., Yadav, J. L., Saini, R. K., Devi, M. (2018): Stored grain pests incidence in wheat with particular reference to Khapra beetle, Tragoderma granarium Everts in southern Haryana, India. - International Journal of Current Microbiology and Applied Sciences 7(3): 2179-2186. 